\title{
ANALYSIS OF THE TOURISTS SATISFACTION IN RELATION TO THE COUNTRY THEY COME FROM WITHIN THE V4
}

\author{
Veronika Kohútová ${ }^{1}$
}

DOI: https://doi.org/10.31410/ERAZ.2019.141

\begin{abstract}
The aim of this study is to identify the relations considering from which countries the visitors are and how satisfy they are. During our survey we found out there are four major nationalities that have visited Slovak destinations - Slovaks, Czechs, Hungarians and inhabitants of Poland, as well as we call this group of states V4 (Visegrad Group). By using linear regression, we reveal if there is a relation between satisfaction and nationality of tourists in chosen destinations, national parks - Pieniny, Slovak Paradise and well known High Tatras - and how the findings differ.

The respondents' satisfaction was determined by a questionnaire survey asked in destinations, where it was necessary to evaluate the various attributes with which the visitor meets during the holiday or trip. Attributes included services, potential and development of destination, as well as insight into various other factors visible in the national park. Overall, we identified 16 attributes and evaluated in the $R$ program. The results are tables with numerical representations of the effect of the variables.
\end{abstract}

Keywords: satisfaction in tourism, Slovak tourist destinations, linear regression.

\section{INTRODUCTION}

S piš, as a region in Slovakia, is often called the pearl of Slovakia, not only typical of its dialect $\checkmark$ and cultural habits, but also known in terms of natural heritage. Tourism is very widespread and important for many entrepreneurs. Other authors [1] also describe that tourism in general is recognized as one of the key development sectors in all countries, and also represents a major source of income, jobs and wealth creation. It plays a vital role in promoting the image and perception of the country at international level, and also affects domestic policy. This scale of impact and importance creates challenges to measure tourism competitiveness.

Based on statistics from previous years, we can see some increase in the number of tourists visiting Slovakia as a destination for trips or holidays. The number of visitors in accommodation facilities is shown in Table 1 below - growth is visible except in 2014 (probably due to adverse weather and currency developments) - by more than $25 \%$ of visitors used accommodation facilities in 2018 compared to 2013. If to mention the countries that visit Slovakia, there is the Czech Republic, which covers almost a third of all foreign visits. It is also important to mention other active tourists from Poland, Germany, Hungary and many others from Europe and around the world, also significantly from Asia [2].

Anyway, traveling has changed compared to the past and is more considered as a trend or lifestyle. Many people go on holiday more than once a year and a common trip abroad is no longer exceptional. Trips and vacations become a more productive experience, destination information is very easy to access on the internet, and travel blogging is a popular topic from the social media perspective. A variety of bloggers are showing how to travel cleverly and cheaply, and even a weekend

Department of Mathematical Methods and Managerial Informatics, Faculty of Management, University of Presov, Konštantínova 16, 08001 Prešov, Slovakia 
outside the country may not be the privilege of the rich. People find the feelings of satisfaction and fulfillment of needs that are currently different from the previous generation. We can also see an increase in the number of domestic guests in accommodation facilities in Slovakia, which represents an even higher proportion of visitors than foreign ones. According to [3], visitors prefer rather shorter holidays and longer weekends than long-term summer holidays. The authors describe that the change in visitor behavior is noticeably observed, their mobility is higher, when they look for adventures and experiences and more various destinations may be visited during one vacation.

Table 1: Number of visitors in Slovak accommodations in years 2013 - 2018.

\begin{tabular}{|c|c|c|}
\hline Years & Total visitors & Foreigners out of it \\
\hline 2018 & 5596407 & 2256027 \\
\hline 2017 & 5375475 & 2162384 \\
\hline 2016 & 5023629 & 2027009 \\
\hline 2015 & 4330249 & 1721193 \\
\hline 2014 & 3727710 & 1475017 \\
\hline 2013 & 4048505 & 1669948 \\
\hline
\end{tabular}

\section{MATERIAL AND METHODS}

We want to evaluate the image of three selected destinations in Slovakia - the well-known High Tatras National Park, the Slovak Paradise National Park and the Pieniny National Park, which is shared with the neighboring country - Poland. In the above-mentioned destinations, the survey and the data collecting were carried out, preferably in a personal form. The survey consisted of a questionnaire where the main part was to decide how satisfied the respondent is with the different attributes in the destination by using Likert Scale from 1 to 5 (from very dissatisfied to very satisfied).

We consider respondents from all three tourist destinations as our research sample; they were classified demographically from which country they come from. The respondents were specific visitors who visited the destination, were able to objectively express their satisfaction with the various attributes during a trip or holiday. Together we received answers from 331 respondents, who were primarily from our country, the Czech Republic, Poland and Hungary, but people from other 6 different countries also participated to a lesser extent in the research. However, we take into consideration 314 responses which were from participants from V4 countries. The most questionnaires were collected in the High Tatras. Following we present specific numbers of respondents:

- 99 respondents in Pieniny National Park,

- 98 respondents in the Slovak Paradise National Park,

- 117 respondents in the High Tatras National Park.

\section{SURVEY ANALYSIS AND LINEAR REGRESSION RESULTS}

We compiled data file in Excel consisting of survey data obtained. Then we created own value called "Sat" (as a "satisfaction") for each response, which means overall average satisfaction value from all the respondent's answers of the attributes. Respondent was instructed to not rate irrelevant attributes (e.g. accommodation facilities if was not accommodated).

Then we could use our data file in R program to obtain data for further interpretations of our desired regression. From this command we wanted to learn what is the satisfaction of the Slovaks 
visited High Tatras destination, in comparison with other respondents from the V4 countries and also in comparing two other destinations - Slovak Paradise and Pieniny.

Table 2: Regression statistics of all satisfaction attributes towards High Tatras and respondents from Slovak republic

\begin{tabular}{|l|c|c|}
\cline { 2 - 3 } \multicolumn{1}{c|}{} & Estimate & P-value \\
\hline Intercept & 3.83720 & $<2 \mathrm{e}-16$ \\
\hline Pieniny & -0.04602 & 0.60614 \\
\hline Slovak Paradise & -0.36715 & $5.01 \mathrm{e}-05$ \\
\hline CR & 0.20181 & 0.03473 \\
\hline PL & 0.23230 & 0.00755 \\
\hline HU & 0.12732 & 0.28581 \\
\hline
\end{tabular}

It follows from the data in Table 2 that respondents from Slovakia were satisfied in the High Tatras at the level of 3.83720 points (in satisfaction assessment from 1 - very dissatisfied to 5 - very satisfied). The p-value is very low, almost equal to 0 . We can consider this P-value reliability test condition to be significant and valid. In doing so, the p-value is conventionally recognized at a rate of $5 \%$, (or value 0.05 ), that is the smallest level of significance at which we reject the set null hypothesis.

For the Pieniny destination, we obtained the estimated value of the linear regression test of -0.04602 , which we can say that the respondents were slightly less satisfied than in the High Tatras, but the informative value of this figure is relatively low according to $p$-value of 0.60614 , which is significantly higher than 0.05 .

Respondents in the Slovak Paradise were -0.36715 points less satisfied than in the High Tatras and we rate this figure as reliable according to the p-value test. The reasons why the perception of the Tatra destination is more positive may be several and seem more understandable. The Tatras are our highest mountains in the country, and many foreign tourists come to Slovakia just because of their visit, but many of the locals used to spend their holidays here as well. When it comes to the fact that it is the most well-known national park with high traffic, then we see a better infrastructure, a greater variety of services, or a more massive awareness of known places in the media, as well as directly in the destination.

An important difference between parks is, for example, accessibility. All the trains and buses from east to west along this route arrive to Poprad, the main starting point of the Tatras. From Poprad it is easy to transfer by bus, electric railway or passenger train to even closer areas of the region and get directly to the important centers. Compared to the Slovak Paradise, accessibility is also much disadvantaged because of its location, but also due to insufficient transport connections. According to routine schedules, getting to resorts like Čingov, Podlesok or Spišské Tomášovce is quite complicated (sometimes impossible), compared to a more famous destination.

Poles (0.23230 points with a valid p-value test), as well as Czechs (0.20181), are more satisfied to local visitors - Slovaks. We consider this phenomenon to be that sometimes it is natural for home visitors to see much more deficiencies than strangers. For foreigners coming to a destination with some expectations, it is more likely that their motivation to get to know the site is higher than assessing the current status of the site.

According to a study by Malaysian authors [4], the tourist behavior is affected by internal and external factors. These tourists choose to go on vacation because they want to fulfill their inner 
desires and also their decisions where to go are based on the different attributes of the destination. We can add that the citizens themselves may look differently to the domestic and foreign destinations in some respect, and some local respondents who came to the national park for the purpose of hiking in the mountains participated in the survey too. The destination is usually also well known for those respondents, its evaluation may be more skeptical and therefore they could influence the results of this analysis that they might were less satisfied than foreign visitors.

To expand the analysis, we decided to select 5 types of services in destinations, namely: accommodation services; catering services; transport options; shopping opportunities; cultural - entertaining opportunities - of which we obtained the average satisfaction values of the respondents, and by the very similar coding in the $\mathrm{R}$ program we obtained the following data recorded in Table 3.

Table 3: Regression statistics of selected satisfaction attributes towards High Tatras and respondents from Slovak republic

\begin{tabular}{|l|c|c|}
\cline { 2 - 3 } \multicolumn{1}{c|}{} & Estimate & P - value \\
\hline Intercept & 3.75933 & $<2 \mathrm{e}-16$ \\
\hline Pieniny & -0.23570 & 0.029051 \\
\hline Slovak Paradise & -0.64827 & $4.83 \mathrm{e}-09$ \\
\hline CR & 0.21657 & 0.060925 \\
\hline PL & 0.38412 & 0.000265 \\
\hline HU & 0.08161 & 0.569940 \\
\hline
\end{tabular}

The biggest difference can be seen in the Slovak Paradise National Park, which is more than half point lower than in the High Tatras National Park, which means that overall satisfaction in the defined 5 types of services is significantly worse compared to the leading destination and then 0.24 points in the rating satisfaction of the Pieniny National Park is rated worse too.

Other valid result worthy of mention is the increased positive satisfaction of Poles in the destination. We register they feel satisfied more than 0.38 point than Slovaks with the selected services.

As already mentioned in the previous interpretations, the High Tatras are clearly better equipped with services, whether they are many options of transport or other as well as wide offer of accommodations and food possibilities.

If we evaluate cultural and entertainment opportunities, it is evident and measurable how many events are organized in the center. After a random search we register several events in all the resorts, but for example in the surroundings of Pieniny there are many in Stará Lubovňa in the castle or in the spa. Stará L'ubovňa is $28 \mathrm{~km}$ from the Pieniny's important center Červený Kláštor and geographically it is not located in the national park. For comparison, many events in the High Tatras are organized more concentrated near the towns of Štrbské Pleso, Tatranská Polianka, Starý Smokovec, Hrebienok, which can be considered as events directly in the destination. Then in the resorts of Slovak Paradise - Podlesok and Hrabušice, 7 major events were organized in year 2018 from May to September, of which 2 were more related to the National Park - Opening of the Infopoint at the kayaking and canoeing starting point in Hrabušické Mýto and kindergarten program called Protecting the Environment with offered horse riding for children. 


\section{CONCLUSION}

By summarizing our study, we can claim there is significant progress in providing services in the High Tatras region compared to the other destinations of Slovak Paradise and Pieniny. This fact was proved by the described linear regression test, where the satisfaction of respondents from the V4 countries in individual destinations was examined. At the same time, we have proven by research that foreign visitors are more satisfied than Slovaks. If we specify, the highest level of satisfaction is reported by Poles and then by tourists from the Czech Republic. This conclusion may be due to the fact that perhaps the nature of the people themselves, or perhaps the Polish people, plays a certain role. We used open questions in the survey too, we received many subjective evaluations and comparisons with Poland - the country where the Dunajec river is a border and countries are connected with a bridge, but the services on the Polish side are incomparably better. Paradoxically we may say that it is Poles who are more satisfied than we ourselves are.

We recommend to start comprehensive development strategy mainly for national park Slovak Paradise focused on services and to optimize environment for tourists who come to the destination, those want to stay overnight, raise accommodation and food services as well. Pieniny national park works better with their services, but needs to communicate with region municipality regarding transport services. Both parks may grow by organizing events at site, many people even don't know these parks are localized up to $40 \mathrm{~km}$ from High Tatras and offer other experiences which can be compared with High Tatras destination from nature side. Tourists may get new sight to these beautiful places, which own such potential that just needs to be developed and promoted internationally.

\section{ACKNOWLEDGEMENTS}

This study is one of the outcomes of the research grants 1/0470/18 Economic activity of tourism in the European space and APVV 17-0166 Economic and psychological factors of tourists' expenditures: micro econometric modeling.

\section{REFERENCES}

[1] Dupeyras, A., MacCallum N. (2013) Indicators for Measuring Competitiveness in Tourism: A Guidance Document", OECD Tourism Papers, 2013/02, OECD Publishing. http://www.mlit.go.jp/kankocho/naratourismstatisticsweek/statistical/pdf/2013_OECD_ Tourism_Papers_2013-02.pdf

[2] Statistical office of the Slovak republic (2018) Visitors in accommodation establishments of tourism, In: slovak.statistics.sk. [online]. [cit. 22. April 2019]. Dostupné na internete: https://bit.ly/2EnmmHB

[3] Királ'ová, A., Straka I. (2013) Vliv globalizace na marketing destinace cestovního ruchu. In: Vašaničová P. (2018) Cestovný ruch a ubytovacie zariadenia Slovenska: Motívy účasti a analýza návštevnosti, Prešov: Vydavatel'stvo Prešovskej univerzity. 2018, ISBN: 978-80555-2065-0.

[4] Al-Haj Mohammad, B. A. M., Mat Som, A. P. (2010) An Analysis of Push and Pull Travel Motivations of Foreign Tourists to Jordan. International Journal of Business and Management, Vol. 5, No. 12, pp. $41-50$. 